\title{
Are We Culturally Corrupt? Revisiting the Relationship between Cultural Dimensions And Corruption Perception Index ${ }^{1}$
}

\author{
Indra Soeharto \& Nugroho \\ indrasoeharto@yahoo.com \& nnugroho@live.com
}

ARTICLE INFORMATION

Article history:

Received Sept 15, 2017

Revised Nov 02, 2017

Accepted Dec 11, 2017

JEL Classifications

K29; K49

Key Words:

Corruption;

Corruption Perception Index;

Cultural Dimensions;

Power Distance;

Masculinity

DOI:

10.21532/apfj.001.17.02.02.02

\begin{abstract}
This research aims to revisit the relationship between two cultural dimensions index (masculinity and power distance) and corruption - as indicated in the Corruption Perception Index (CPI). Two hypotheses were proposed: An increase in the masculinity index increases corruption and an increase in the power distance index increases corruption. Using the latest CPI data from 2012 to 2016 of 67 countries, this research found that the increase in masculinity does not significantly increase corruption. Meanwhile, it is noticed that the increase in power distance significantly increases corruption. Better understanding on such relationship will provide valuable input on how cultural approach is important to fine tune the design of corruption eradication strategy, particularly in Indonesia.
\end{abstract}

At the end, proper strategy will contribute the improvement of Indonesia's CPI, which will eventually improving Indonesia's business environment for the investo

\section{Introduction}

Post 1998 crisis, the term "KKN" (Korupsi, Kolusi, Nepotisme - Corruption, Collusion and Nepotism) has commonly named as the main causes of the monetary crisis that eventually end the Soeharto Regime. For 32 years of the "Orde Baru" (new order era), the practices of Corruption, Collusion and Nepotism have been widely accepted and applied as normal practice, mainly in government sector. Asset misappropriation, financial statement fraud and corruption are several popular modes of occupational fraud (ACFE, 2016).

Since then, KKN has formally become common enemy that need to be eradicated. Various preach, efforts and initiatives to eradicate corruption practices in Indonesia have been launched. Anti Corruption law was enacted in 2001, this law is the basis of the establishment of KPK (Commission of Corruption Eradication). KPK focuses on

1 The 1st Runner Up National Call For Paper ACFE Indonesia Chapter 2017 
both preventive and curative effort to eradicate corruption that causes state's loss.

In a wider scope, since 1996, Transparency International (TI), an international NGO that focuses on corruption, has annually issued the Corruption Perception Index (CPI). TI issued a rank of countries based on the perception of corruption. After almost 2 decades, Indonesia's CPI is slowly improving. Despite the existence of KPK, corruption practices are still commonly found in Indonesia. Why is this happening? What makes Indonesia sustain its low CPI despite of the existence of various efforts against corruption?

Before looking for ways on how local wisdom could take a role in corruption eradication strategy, we opted to first answer this question: Could it be the corruption is culturally embedded in Indonesia - which makes corruption difficult to eradicate?

As various previous research suggest, cultural dimensions have specific relationship with corruption practices in a country. Using the newest data of CPI (2012-2016), this paper aims to revisit the relationship between these two variables of cultural dimensions and corruption.

Better understanding on such relationship will provide valuable input on how cultural approach is important to fine tune the design of corruption eradication strategy, particularly within Indonesia's context. At the end, proper strategy will contribute the improvement of Indonesia's CPI, which will eventually improving Indonesia's business environment for the investors.

\section{Definition}

Corruption seems to be the neverending chronic cause of chaotic governance within an institution, or even a nation. Although numerous literatures portray the notion of corruption through exhaustive research and study, the meaning of corrupt acts evolves. However, the essence of corrupt acts remains, which is a misuse of power and authority by committing to unethical conduct for personal gain.

Corrupt acts can sometimes be unavoidable especially in doing business, which ranged from offering unusual prizes to extortion, in order to obtain favourable decisions to one party or another. Countless initiatives to combat the corruption are put in place, but the number of corrupt individuals grows worryingly in so many ways, indicated by more hypocrite officials busted by law enforcement. This state affirms that corruption breeds corruption and the longer it persists the more endemic it becomes (Ali, a. \& Isse, 2003).

A prominent psychologist, Geert Hofstede, introduced the concept the cultural dimensions, which affect country's corruption level. His research highlighted two essential dimensions: Masculinity and Power Distance.

Masculinity relates to allotment of responsibility between men and women. Men tend to be aggressive and competitive, especially in pursuing their desire at work or at any given opportunity. However, the term "masculinity" is not exclusively attached to gender "male," but it represents the domination of masculinity traits in which a country practically hold (Hofstede, 1997).

Indeed, women in masculine countries have those aggressiveness and competitiveness characters at some extent. On the contrary, feminine cultural dimension embraces the value of modesty and caring to one-another. Countries with low masculinity score, or more feminine, respect the relationships with people above wealth and they are "minding the quality of life and the preservation of the environment" (Hofstede, 1997). In these countries, women are respected equally within the society and having women in strategic position in government or in an enterprise are considered normal. 
Second cultural dimension is Power Distance, which appoints to the extent to which the less powerful members of the organizations and institutions accept and expect the power is distributed unequally (Hofstede, 2011). This dimension points out those who have the power and authority, and to those who lack of that quality. Countries with noticeable power distance score are more coercive in governing the society. Leaders and executives are predominant, and the rest are subordinates who have limited access to equal treatment. The states are often the goldmines for elite and powerful administration while the citizens are somehow marginalized.

\section{Previous Research}

Researchers and academics have profoundly examined the issue of these two cultural dimensions and corrupt acts in a country. Although different variable and approach have been implemented to assess their relationship, the outcome tends to show positive correlation. The masculine values of aggressiveness and materialism provoke a higher level of corruption than do feminine (Seleim, A. \& Bontis, N, 2009). In addition, if social status and wealth possessions are strongly adored, a corrupt act is truly a temptation.

In countries with lower power distance, superiors and regular citizens tend to interact seamlessly as they see themselves as equal in both status and authority. Such will rarely found in countries with higher power distance level. Inequality among society is indeed treated as an opportunity to act corruptly, especially for superiors, since only few or even nobody will have the courage to counter attack them in not doing so (Tanzi, 1998).

McLaughlin (2013) found out that Scandinavian, such as Finland and Sweden, are countries which have the lowest masculinity level, and certainly low corruption index. These countries enjoy the prosperity and peace of living. In contrast, African countries such as
Kenya and Nigeria, with high masculinity and power distance score are arguably have higher corruption index.

By understanding how these cultural dimensions interact with corruption level of a country, government and organisation are expected to be more cautious in formulating policies, in particular on how to better eradicate the corrupt practices.

\section{Methodology}

To measure the dependent variable, corruption, we use the data derived from Transparency International (TI). Since 1996, TI publishes the Corruption Perception Index (CPI) scores for more than 100 countries. The index is drawn based on different assessments and business opinion surveys. On this research, we collect the latest CPI data from year 2012 to 2016. Based on those data, we calculate the average CPI of each country.

The CPI ranks countries according to the perception of corruption in the public sector. TI ranks each country on a scale from 0 to 100 with 0 being the most corrupt and 100 being the least corrupt. In order to make these values more comparable to the independent variables score, we first converted the scores by dividing each country's score by 10 . Secondly, we inverted the scores by subtracting each country's score from 10. This made 10 the most corrupt country and a score of 0 the least corrupt.

The independent variables are masculinity and power distance. Both cultural dimensions were based on cultural dimensions scores from earlier studies that performed by Hofstede. Hofstede analyzed a large database of employee values scores collected by IBM employees covering more than 70 countries. Hofstede created an index score for each of the dimensions that ranged from 0 to 100 (Hofstede, 1997).

In order to make these values more intuitive in comparison to CPI, we converted 
the scores by dividing each country's score by 10. This made 10 the highest power distance and masculinity, and a score of 0 as the least.

Although Hofstede's measures have been widely criticized (Venaik, S. \& Brewer, P., 2008) other studies, as mentioned on Seleim, A \& Bontis, N. (2009) have supported his measures.

\section{Hypotheses}

Previous researches have established a positive relationship between masculinity and corruption. Country with high masculinity will tend to have high corruption.

\section{Hypothesis 1: An increase in the masculinity index increases corruption.}

Previous researches have established a positive relationship between power distance and corruption. Country with high power distance will tend to have high corruption.

\section{Hypothesis 2: An increase in the power distance index, increases corruption.}

\section{Results}

Having collected the data, there are 67 countries that have complete data of all index: masculinity, power distance and CPI.

Table 1 shows the CPI average score for 67 countries from 2012 to 2016. Masculinity and power distance index are also presented in this table.

It is particularly noted that with an above average CPI score, Indonesia also has high power distance index and moderate masculinity index - compared to other countries.

Table 1

\begin{tabular}{r|l|r|r|r|} 
No & Countries & Masculinity & Power Distance & Corruption Perception Index \\
\hline 1 & Argentina & 5.60 & 4.90 & 6.58 \\
\hline 2 & Australia & 6.10 & 3.60 & 1.92 \\
\hline 3 & Austria & 7.90 & 1.10 & 2.78 \\
\hline 4 & Bangladesh & 5.50 & 8.00 & 7.42 \\
\hline 5 & Belgium & 5.40 & 6.50 & 2.40 \\
\hline 6 & Brazil & 4.90 & 6.90 & 5.88 \\
\hline 7 & Bulgaria & 4.00 & 7.00 & 5.86 \\
\hline 8 & Canada & 5.20 & 3.90 & 1.78 \\
\hline 9 & Chile & 2.80 & 6.30 & 2.96 \\
\hline 10 & China & 6.60 & 8.00 & 6.16 \\
\hline 11 & Colombia & 6.40 & 6.70 & 6.34 \\
\hline 12 & Costa Rica & 2.10 & 3.50 & 4.52 \\
\hline 13 & Czechia & 5.70 & 5.70 & 4.82 \\
\hline 14 & Denmark & 1.60 & 1.80 & 0.92 \\
\hline 15 & Ecuador & 6.30 & 7.80 & 6.74 \\
\hline 16 & Estonia & 3.00 & 4.00 & 3.18 \\
\hline 17 & Finland & 2.60 & 3.30 & 1.06 \\
\hline 18 & France & 4.30 & 6.80 & 3.00 \\
\hline 19 & Germany & 6.60 & 3.50 & 2.04 \\
\hline 20 & Great Britair & 6.60 & 3.50 & 2.20 \\
\hline 21 & Greece & 5.70 & 6.00 & 5.82 \\
\hline 22 & Guatemala & 3.70 & 9.50 & 7.00 \\
\hline 23 & Hong Kong & 5.70 & 6.80 & 2.44 \\
\hline 24 & Hungary & 8.80 & & 6.76 \\
\hline 25 & India & & & \\
\hline & & & & \\
\hline
\end{tabular}


Table 1 (continued)

\begin{tabular}{|c|c|c|c|c|}
\hline No & Countries & Masculinity & Power Distance & Corruption Perception Index \\
\hline 26 & Indonesia & 4.60 & 7.80 & 6.58 \\
\hline 27 & Ireland & 6.80 & 2.80 & 2.74 \\
\hline 28 & Iran & 4.30 & 5.80 & 7.28 \\
\hline 29 & Israel & 4.70 & 1.30 & 3.88 \\
\hline 30 & Italy & 7.00 & 5.00 & 5.62 \\
\hline 31 & Jamaica & 6.80 & 4.50 & 6.12 \\
\hline 32 & Japan & 9.50 & 5.40 & 2.58 \\
\hline 33 & Korea (South) & 3.90 & 6.00 & 4.50 \\
\hline 34 & Luxemburg & 5.00 & 4.00 & 1.92 \\
\hline 35 & Malaysia & 5.00 & 10.00 & 5.00 \\
\hline 36 & Malta & 4.70 & 5.60 & 4.42 \\
\hline 37 & Mexico & 6.90 & 8.10 & 6.64 \\
\hline 38 & Morocco & 5.30 & 7.00 & 6.28 \\
\hline 39 & Netherlands & 1.40 & 3.80 & 1.60 \\
\hline 40 & New Zealand & 5.80 & 2.20 & 1.00 \\
\hline 41 & Norway & 0.80 & 3.10 & 1.42 \\
\hline 42 & Pakistan & 5.00 & 5.50 & 7.08 \\
\hline 43 & Panama & 4.40 & 9.50 & 6.26 \\
\hline 44 & Peru & 4.20 & 6.40 & 6.30 \\
\hline 45 & Philippines & 6.40 & 9.40 & 6.44 \\
\hline 46 & Poland & 6.40 & 6.80 & 3.94 \\
\hline 47 & Portugal & 3.10 & 6.30 & 3.74 \\
\hline 48 & Romania & 4.20 & 9.00 & 5.52 \\
\hline 49 & Russia & 3.60 & 9.30 & 7.18 \\
\hline 50 & Singapore & 4.80 & 7.40 & 1.48 \\
\hline 51 & South Africa & 6.30 & 4.90 & 5.64 \\
\hline 52 & Salvador & 4.00 & 6.60 & 6.20 \\
\hline 53 & Slovakia & 10.00 & 10.00 & 5.10 \\
\hline 54 & Spain & 4.20 & 5.70 & 4.00 \\
\hline 55 & Sweden & 0.50 & 3.10 & 1.18 \\
\hline 56 & Switzerland & 7.20 & 2.60 & 1.42 \\
\hline 57 & Taiwan & 4.50 & 5.80 & 3.88 \\
\hline 58 & Thailand & 3.40 & 6.40 & 6.34 \\
\hline 59 & Trinidad & 5.80 & 4.70 & 6.22 \\
\hline 60 & Turkey & 4.50 & 6.60 & 5.46 \\
\hline 61 & Uruguay & 3.80 & 6.10 & 2.74 \\
\hline 62 & United States & 6.20 & 4.00 & 2.60 \\
\hline 63 & Venezuela & 7.30 & 8.10 & 8.16 \\
\hline 64 & Vietnam & 4.00 & 7.00 & 6.86 \\
\hline 65 & Croatia & 4.00 & 7.30 & 5.16 \\
\hline 66 & Serbia & 4.30 & 8.60 & 5.92 \\
\hline 67 & Slovenia & 1.90 & 7.10 & 4.06 \\
\hline
\end{tabular}


As shown in Table 2, corruption perception index tends to have more variation, as measured by the coefficient of variation than power distance (PD) or masculinity (MAS).

\begin{tabular}{|l|r|l|r|r|r|r|}
\hline Variable & Gbs & Mean & Std. Dev & Coef Var & Min & Max \\
\hline MAS & 67 & 5.00 & 1.88 & 0.37 & 0.50 & 10.00 \\
\hline PD & 67 & 5.88 & 2.18 & 0.37 & 1.10 & 10.00 \\
\hline CPI & 67 & 4.50 & 2.03 & 0.45 & 0.92 & 8.16 \\
\hline
\end{tabular}

\section{Table 2}

After performing tests of correlation - presented in Table 3 and Table 4, it is found that there is a high degree of correlation between CPI and power distance, which support the second hypothese of this paper. However, it is also noted that the correlation between CPI and masculinity was low.

Table 3

\begin{tabular}{|l|r|r|r|}
\hline & & MAS & CPI \\
\hline MAS & 1.0000 & & \\
\hline PD & 0.0906 & 1.0000 & 1.0000 \\
\hline CPI & 0.1855 & 0.6555 & \\
\hline
\end{tabular}

Table 4

\begin{tabular}{|l|r|r|}
\hline Coef of Determination & PD-CPI & M-CPI \\
\hline $\mathbf{R}^{\mathbf{2}}$ & 0.4292 & 0.0344 \\
\hline
\end{tabular}

\section{Conclusion and Implications}

This research aims to revisit the relationship between two cultural dimensions index (masculinity and power distance) and corruption - as indicated in the Corruption Perception Index (CPI). Two hypotheses were proposed: An increase in the masculinity index increases corruption and an increase in the power distance index increases corruption.

Using the latest CPI data from 2012 to 2016 of 67 countries, it is found that the increase in masculinity does not significantly increase corruption. Meanwhile, it is noticed that the increase in power distance significantly increases corruption.

Refer to those findings, although the second hypotheses was confirmed, we however could not confirm the first hypothese, as the correlation was low. From these findings, it can be inferred that the increase of masculinity in a country does not significantly affect the increase of corruption level of that country. In the contrary, the increase of power distance will significantly affect the increase of corruption level in that country.

From corruption eradication perspective, the result of this study could give an entry point for corruption prevention efforts. For example, prevention of corruption could be started from the top, by introducing various initiatives to lowering down the power distance. In addition to various conventional strategies to combat the corruption, cultivation of egalitarian culture - which may lead to lower power distance - should be initiated in an organisation as one of the strategy to combat corrupt practices.

Conclusively, it is an important necessity to better understand our own culture and its impact to corruption prevention and eradication. Taking into account cultural insights on corruption prevention and eradication strategy formulation and followed by proper strategy 
implementation shall provide promising result of the war against corruption.

In the long run, such strategies are expected to decrease the corruption level in our country. Accomplishing that objective will provide evidence that corruption is not our embedded culture, and will finally offer better investment environment for investors.

\section{References}

ACFE, Report to the Nations on Occupational Fraud and Abuse, retrieved from http:// www.acfe.com/

Ali, a. \& Isse, H.S. (2003). Determinants of Economic Corruption: a cross-country comparison [Electronic Version], Cato Journal, 22, (3), 449-467

Hill, C. (2009). International Business: Competing in the global marketplace. 7th edition, The McGraw-Hill companies, New York.

Hofstede, G. (1997). Cultures and Organizations: Software of the Mind. McGraw-Hill, New York.

Hofstede, G. (2011). Cultures and Organizations: Software of the Mind. McGraw-Hill, New York.

ITIM International, retrieved from http://www. geert-hofstede.com/

McLaughlin, E (2013). Culture and Corruption: An Explanation of the Differences between Scandinavia and Africa, American International Journal of Research in Humanities, Arts and Social Sciences, 2(2), March-May, 2013, pp. 8591

Seleim, A \& Bontis, N. (2009). The relationship between culture and corruption: a crossnational study. Journal of Intellectual Capital, 10 (1), 166-184.
Tanzi, V. (1998). Corruption around the world: Causes, consequences, scope, and cures [Electronic version]. International Monetary Fund Staff Papers - International Monetary Fund, 45, (4), 559-595.

Transparency International - Corruption Perception Index (2012-2016) retrieved from http://transparency.org.

Venaik, S. \& Brewer, P. (2008). Contradictions in national culture: Hofstede versus GLOBE [Electronic version]. Paper presented at the 2008 Academy of International Business Conference, Track 8 . 
Indra Soeharto \& Nugroho : Are we culturally corrupt? revisiting the....

Page 143-149

\section{Asia Pasific Fraud Journal}

Volume 2, No.2 ${ }^{\text {nd }}$ Edition (July-December 2017) 